Jurnal Psikologi Teori dan Terapan

2016, Vol. 7, No. 1, 9-15, ISSN: 2087-1708

\title{
Self Disclosure dan Trust Pada Pasangan Dewasa Muda yang Menikah dan Menjalani Hubungan Jarak Jauh
}

\author{
Ana Suryani, dan Desi Nurwidawati \\ Program Studi Psikologi Universitas Negeri Surabaya
}

\begin{abstract}
This research is aimed to test the correlation between self disclosure and trust among married people experiencing long distance relationship. This research used quantitative method with correlational research design. Participants in this research were 34 people whose spouses are in other cities or overseas with a chance of meeting is no more than once in a month. Participants were selected using snowball sampling. This research used self disclosure and trust scales to collect data and data were analysed using Rank Spearman test. The result shows that coeficient correlation ( $r$ ) is 0,656 and the significance value is 0,000 ( $p>0,05)$, which means that the hypothesis of this research "there is correlation between self disclosure and trust among adult married people experiencing long distance relationship" is accepted.
\end{abstract}

Keywords: self disclosure, trust, long distance relationship.

\begin{abstract}
Abstrak: Penelitian ini bertujuan untuk menguji hubungan self disclosure dengan trust pada pasangan dewasa muda yang menikah dan menjalani hubungan jarak jauh. Penelitian ini menggunakan metode penelitian kuantitatif dengan rancangan penelitian korelasional. Partisipan penelitian ini berjumlah 34 orang yang memiliki karakteristik berusia dewasa muda yang telah menikah dan sedang menjalani hubungan jarak jauh dengan pasangannya baik luar kota maupun luar negeri dengan intensitas bertemu setidaknya satu kali perbulan. Teknik sampling dalam penelitian ini menggunakan snowball sampling. Penelitian ini menggunakan instrumen skala self disclosure dan skala trust. Analisis data yang digunakan adalah Rank Spearman test. Hasil analisis koefisien korelasi menunjukkan (r) sebesar 0,656 dan nilai signifikasi $0,000(p>0,05)$, artinya analisis tersebut menunjukkan bahwa hipotesis "ada hubungan self disclosure dengan trust pada pasangan dewasa muda yang menikah dan menjalani hubungan jarak jauh" diterima.
\end{abstract}

Kata Kunci: self disclosure, trust, hubungan jarak jauh.

Hubungan jarak jauh atau long distance relationship merupakan jenis hubungan yang sulit untuk dijalani. Apalagi pada pasangan yang telah menikah. Hubungan jarak jauh atau yang sering disebut long distance relationship adalah dimana pasangan dipisahkan oleh jarak fisik yang tidak memungkinkan adanya kedekatan fisik untuk periode waktu tertentu (Hampton, 2004).

Beberapa peneliti menganggap keterpisahan fisik untuk periode waktu tertentu sebagai salah satu faktor yang membedakan hubungan jarak jauh dengan hubungan jarak dekat. Hubungan jarak jauh pada pasangan yang telah menikah

Korespondensi tentang artikel ini dapat dialamatkan kepada Ana Suryani melalui email: ana_psi87@ymail.com 
meningkat pesat dalam kebudayaan barat. Menurut The former center for the study of long distance relationships, $2,9 \%$ dari pernikahan yang ada di Amerika Serikat menjalani hubungan jarak jauh pada tahun 2005. Satu dari sepuluh pernikahan dilapormengalami hubungan jarak jauh pada tiga tahun pertama, ini berarti pada tahun 2005 sekitar 3.569.000 juta orang di Amerika Serikat terlibat dalam hubungan jarak jauh. Data ini menunjukkan peningkatan, dimana pada tahun 2000 di Amerika hanya ada 839.000 orang yang menjalani hubungan pernikahan jarak jauh.

Dukungan teknologi saat ini semakin berkembang, namun pada pasangan jarak jauh tetap tidak terlepas dari tantangan-tantangan yang harus dihadapi. Tantangan tersebut antara lain berkurangnya kontak tatap muka, tidak dapat mengamati langsung apa yang dilakukan pasangan, keterbatasan komunikasi, rasa curiga dan cemburu akibat besarnya kemungkinan pasangan tidak setia, serta sulit menyelesaikan masalah dalam jarak (Aylor, 2003). Masalah-masalah seperti ini adalah masalah yang paling banyak terjadi pada hubungan jarak jauh. Dainton \& Aylon (2001) juga mengungkapkan bahwa adanya ketidakpastian hubungan lebih mungkin terjadi dalam hubungan jarak jauh karena jarak fisik merupakan sumber utama dalam ketidakpastian suatu hubungan. Aylor (2003) juga menambahkan bahwa hubungan jarak jauh dipercaya dapat menghasilkan kepuasan hubungan yang rendah. Kepuasan hubungan yang rendah dalam hubungan jarak jauh dapat menyebabkan stress, strategi penyelesaian masalah yang kurang efektif diantara pasangan, dan menurunnya tingkat kepercayaan pada pasangan (Lee-Ji-Yeon, 2012).

Maraknya kasus perceraian yang disebabkan oleh hubungan jarak jauh, ketidakharmonisan dalam keluarga, dan kurangnya komunikasi juga menjadi tantangan tersendiri bagi pasangan hubungan jarak jauh. Berita yang dimuat dalam media online Lensaindonesia.com pada Senin, 17 Desember 2012 dimana pemicu timbulnya perceraian tertinggi di kabupaten Pacitan menurut PA (Pengadilan Agama) Pacitan adalah disebabkan karena hubungan jarak jauh atau karena salah satu pihak pergi, dalam hal ini tercatat ada 387 perkara dari jumlah 1028 perkara cerai yang diajukan.

Banyuwangi merupakan kabupaten dengan tingkat perceraian yang menempati urutan kedua secara nasional. Setiap hari ada sekitar 500 kasus angka perceraian yang diproses. Penyebab tingginya perceraian di Kabupaten Banyuwangi menurut pengamat sosial, adalah disebabkan banyaknya TKI atau tenaga kerja Indonesia khususnya wanita yang bekerja ke luar negeri sehingga muncul ketidakharmonisan keluarga hingga perselingkuhan (www.dprd.jatim.go.id).

Berita yang dimuat di beritajatim.com pada tanggal 14 Januari 2015 juga mengungkapkan data percerain di Banyuwangi yang terus meningkat. Menurut PA (Pengadilan Agama) Kabupaten Banyuwangi pada tahun 2014, Banyuwangi mengalami kenaikan angka perceraian, dari 6.930 pada tahun 2013 menjadi 7.106.

Menurut Musdalifah (2012) Indonesia adalah salah satu Negara dengan tingkat perceraian yang tinggi, sebagian besar penyebab perceraian adalah karena masalah ketidakharmonisan, tidak bertanggung jawab dan masalah ekonomi. Rekapitulasi Badan Peradilan Agama (BPA) tahun 2010, dari 285.184 perceraian, 91.841 kasus karena ketidakharmonisan (perselingkuhan, masalah komunikasi, dan sebagainya), 78.407 karena tidak bertanggung jawab dan 67.891 karena masalah ekonomi.

Usia pernikahan juga sangat mempengaruhi perceraian yang terjadi pada dewasa muda. Menurut Gustafson 
(2006) kebanyakan pasangan menikah yang menjalani hubungan jarak jauh diusia pernikahan lebih muda dengan anak yang masih kecil (kurang dari 13 tahun) serta pengalaman akan perpisahan tidak banyak merupakan pasangan yang paling rapuh dibandingkan dengan pasangan yang lebih tua, dimana pasangan yang lebih tua dan mempunyai banyak pengalaman akan perpisahan dengan pasangan lebih dapat beradaptasi terhadap perjalanan dinas karena pekerjaan dan bahkan merasakan periode yang berturut-turut anatara perpisahan dan reuni sebagai hal yang sangat menarik.

Secara spesifik, tantangan yang dihadapi oleh pasangan yang menjalani hubungan jarak jauh dapat menghasilkan sejumlah hal yang negatif, namun tidak sedikit pula pasangan jarak jauh yang berhasil melanggengkan hubungan mereka. Hambatan dalam hubungan jarak jauh memerlukan adanya sikap dan strategi yang tepat. Adapun hasil penelitian yang dilakukan Dainton \& Aylon (2001) bahwa kepercayaan (trust) menjadi salah satu strategi dalam mengurangi ketidakpastian bagi individu yang sedang membangun hubungan dan menjadi hal yang penting dalam mengurangi ketidakpastian hubungan. Hal tersebut juga sejalan dengan hasil penelitian yang dilakukan oleh Kauffman (2000) yang juga menemukan bahwa trust merupakan syarat keberhasilan hubungan jarak jauh, dimana banyak respondennya yang meyakini trust sebagai kekuatan hubungan mereka.

Hasil penelitian yang dilakukan Gonzales (2011) menunjukkan bahwa kepercayaan (trust) merupakan prediktor dalam kepuasan hubungan jarak jauh. Hal ini dikarenakan seseorang tidak dapat mengobservasi secara langsung perilaku pasangannya, sehingga dibutuhkan kepercayaan dalam menjalani hubungan jarak jauh tersebut.

Menurut Johnson \& Johnson (2012) trust atau kepercayaan merupakan aspek dalam suatu hubungan dan secara terus menerus berubah serta bervariasi yang dibangun melalui rangkaian tindakan trusting dan trustworthy. Trusting adalah kemauan untuk mengambil resiko terhadap akibat yang baik ataupun buruk, sedangkan trustworthy adalah perilaku yang melibatkan penerimaan terhadap kepercayaan orang lain. Elemen kepercayaan yang paling penting adalah keterbukaan dan saling berbagi (Johnson \& Johnson, 2012).

Nugroho (2013) yang mengungkapkan bahwa self disclosure atau keterbukaan diri dapat membangun keakraban dalam kelompok atau dalam upaya mengatasi konflik, dimana pihak yang terlibat konflik berusaha melakukan pengungkapan diri dan mengajak lawan konfliknya untuk melakukan hal yang serupa yang bisa dibangun saling percaya dan akhirnya saling membuka diri. Johnson (dalam Gainau, 2009) menjelaskan bahwa seseorang yang mampu dalam membuka diri (self disclosure) terbukti mampu menyesuaikan diri (adaptive), lebih percaya diri, lebih kompeten, dapat diandalkan, lebih mampu bersikap positif, percaya terhadap orang lain, lebih objektif, dan terbuka. Hasil penelitian yang lain sama juga mengungkapkan bahwa keterbukaan akan mempengaruhi komunikasi, harapan, dan pada akhirnya berakibat pada hubungan interpersonal serta membuat seseorang berkeinginan untuk berbagi informasi dan berkomuni-kasi, dan hal ini pada akhirnya akan memunculkan kepercayaan (Overwalle \& Heylighen, 2006)

Menurut Devito (2011), self disclosure adalah suatu jenis komunikasi, yaitu pengungkapan informasi tentang diri sendiri yang biasanya disembunyikan. Person (Gainau, 2009) mengartikan self disclosure sebagai tindakan seseorang dalam memberikan informasi yang bersifat pribadi pada orang lain secara sukarela dan disengaja untuk maksud memberi informasi yang akurat tentang dirinya. 
Orang yang menjalin hubungan percintaan memiliki self disclosure yang cukup signifikan satu sama lain. Melalui self disclosure, seseorang akan lebih mengenal diri sendiri, memiliki keintiman hubungan dengan orang lain, lebih mampu menghadapi masalah yang ada karena memperoleh dukungan dan memiliki cukup energi karena, dengan tidak menyimpan rahasia maka beban yang ditanggung pun akan terasa lebih ringan (Devito, 2011).

Pasangan yang sedang menjalani hubungan jarak jauh perlu memiliki strategi positif untuk dapat terus melanggengkan hubungan mereka agar dapat melewati segala hambatan-hambatan yang ada. Adanya self disclosure antar pasangan maka akan mengurangi hambatan dan tantangan dan akan muncul kepercayaan (trust) antar pasangan.

Berdasarkan latar belakang di atas, peneliti tertarik untuk mengetahui apakah ada hubungan self disclosure dengan trust pada dewasa muda yang menikah dan menjalani hubungan jarak jauh.

\section{Metode}

Penelitian ini menggunakan metode penelitian kuantitatif dengan rancangan penelitian korelasional untuk mengungkap hubungan self disclosure dengan trust pada pasangan dewasa muda yang menikah dan menjalani hubungan jarak jauh.

Penelitian ini melibatkan 34 orang dewasa muda yang telah menikah dan menjalani hubungan jarak jauh dengan pasangannya. Teknik pengambilan sampel penelitian dilakukan dengan teknik snowball sampling. Penelitian ini dilaksanakan di Desa Bulurejo, Kecamatan Purwoharjo, Banyuwangi.

Instrumen penelitian yang digunakan adalah skala self disclosure dan skala trust dengan menggunakan model skala likert. Skala self disclosure pada penelitian ini disusun berdasarkan aspek-aspek self disclosure yang dikemukakan oleh Devito (2011). Skala trust pada penelitian ini disusun berdasarkan komponen-komponen trust yang dikemukakan oleh Johnson \& Johnson (2012).

Penelitian ini menggunakan teknik analisis data rank spearman correlation yang bertujuan untuk mengetahui hubungan variabel bebas dengan varibel terikat. Rank spearman correlation digunakan dalam penelitian ini karena jumlah sampel yang sangat sedikit. Analisis dilakukan dengan menggunakan bantuan program SPSS versi 21.00 for windows.

\section{Hasil dan Pembahasan}

Berdasarkan analisis data menunjukkan bahwa nilai koefisien korelasi dari kedua variabel sebesar 0,656 dan nilai signifikasi atau probabilitasnya sebesar $(p)=0,000 \quad(p<0,05) . \quad$ Hasil tersebut menunjukkan bahwa ada hubungan antara self disclosure dengan trust pada pasangan dewasa muda yang menikah dan menjalani hubungan jarak jauh.

Hasil utama dari penelitian ini menunjukkan bahwa ada hubungan yang signifikan self disclosure dengan trust pada pasangan dewasa muda yang menikah dan menjalani hubungan jarak jauh. Hal tersebut senada dengan Nugroho (2013) yang mengungkapkan bahwa self disclosure atau keterbukaan diri dapat membangun keakraban dalam kelompok atau dalam upaya mengatasi konflik, dimana pihak yang terlibat konflik berusaha melakukan pengungkapan diri dan mengajak lawan konfliknya untuk melakukan hal yang serupa. Selanjutnya, bisa dibangun saling percaya dan akhirnya saling membuka diri.

Fenomena yang terjadi pada penelitian ini mengungkapkan bahwa dalam menjalani hubungan jarak jauh, diperlukan strategi komunikasi dan adanya keterbukaan yang tepat kepada pasangan sehingga segala hambatan dan masalah dalam menjalani hubungan jarak jauh seperti adanya keterbatasan komunikasi, rasa curiga dan cemburu akibat besarnya 
kemungkinan pasangan tidak setia, serta sulit menyelesaikan masalah dalam jarak dapat diselesaikan dengan baik dengan adanya kepercayaan terhadap pasangan. Kecanggihan teknologi dan mudahnya berkomunikasi melalui berbagai media sosial juga dimanfaatkan oleh para pasangan yang menjalani hubungan jarak jauh ini sebagai cara melanggengkan hubungan mereka dan dengan cara tersebut dapat meningkatkan keterbukaan mereka satu sama lain sehingga timbul trust (kepercayaan) mereka terhadap pasangan.

Pada pasangan yang menjalani hubungan jarak jauh, kurangnya kehadiran pasangan secara fisik membuat frekuensi untuk melakukan komunikasi verbal juga jarang dilakukan, sehingga keterbukaan diri (self disclosure) menjadi salah satu komponen yang sangat penting untuk meningkatkan keintiman dalam hubungan mengingat komunikasi mereka yang sangat terbatas. Hasil penelitian Falk dan Wagner (2001) menemukan bahwa self disclosure yang progresif akan meningkatkan kesempatan perkembangan sebuah hubungan untuk menjadi lebih intim lagi.

Komunikasi yang baik dengan pasangan ditengah keterbatasan waktu dan saling mengungkapkan apa yang mereka rasakan akan semakin mempererat hubungan dan semakin dapat meningkatkan kepercayaan (trust) diantara pasangan yang sedang menjalani hubungan jarak jauh tersebut. Hasil penelitian yang dilakukan oleh Laureanceau dan Barret (2005) juga menemukan bahwa self disclosure dan keterbukaan pasangan merupakan dua hal yang dapat mempengaruhi kedekataan antara suami dan istri dan respon yang diberikan istri atau suami terhadap apapun yang disampaikan oleh pasangannya akan dapat memberikan dampak terhadap kesediaan pasanggan tersebut untuk lebih terbuka terhadap pasangannya. Adanya komunikasi dan keterbukaan antar pasangan, akan terbentuk kepercayaan antar keduanya. Hal yang sama juga diungkapkan oleh Derlega, Metts, Petrinoi dan Margulis (dalam Seccombe dan Warner, 2004) bahwa self disclosure dapat meningkatkan komunikasi dan hubungan yang baik, meningkatkan kepercayaan terhadap pasangan serta keintiman yang berperan besar terhadap peningkatan kepuasan hubungan perkawinan. Hasil penelitian tersebut menguatkan bahwa ada hubungan antara self disclosure dan trust.

Trust merupakan kunci keberhasilan dalam suatu hubungan setelah adanya komunikasi dan keterbukaan. Hasil penelitian yang lain dilakukan Gonzalez (2011) yang menyebutkan bahwa trust (kepercayaan) terhadap pasangan merupakan elemen yang terpenting terutama pada hubungan jarak jauh. Kauffman (2000) juga melakukan riset tentang trust dan menemukan bahwa kepercayaan (trust) merupakan syarat dalam keberhasilan hubungan jarak jauh, dimana banyak respondennya yang meyakini bahwa kepercayaan sebagai kekuatan hubungan mereka. Kepercayaan yang tinggi membuat individu cenderung memegang harapan yang optimis terhadap motif dari pasangannya, membuat penilaian yang positif terhadap perilaku pasangannya, dan terbuka pada hal-hal baru (Simpson, 2007).

Menurut Rakhmat (2009) ada tiga faktor yang berhubungan dengan trust (kepercayaan) yaitu, karakteristik dan maksud orang lain, hubungan kekuasaan, serta sifat dan kualitas komunikasi. komunikasi yang terbuka, maksud dan tujuan sudah jelas, dan ekspektasi sudah dinyatakan, maka akan tumbuh sikap percaya.

Hasil penelitian ini juga sejalan dengan pendapat yang dikemukakan Overwalle \& Heylighen (2006) yang mengungkapkan bahwa keterbukaan akan mempengaruhi komunikasi, harapan, dan pada akhirnya berakibat pada hubungan interpersonal serta membuat seseorang 
berkeinginan untuk berbagi informasi dan berkomunikasi, dan hal ini pada akhirnya akan memunculkan kepercayaan.

\section{Simpulan}

Berdasarkan hasil penelitian tentang hubungan self disclosure dengan trust pada pasangan dewasa muda yang menikah dan menjalani hubungan jarak jauh, didapatkan hasil yang positif dan signifikan. Hal ini berarti semakin tinggi tingkat self disclosure individu maka semakin tinggi tingkat trustnya dan sebaliknya, semakin tinggi tingkat trust yang dimiliki individu maka semakin tinggi juga tingkat self disclosure individu tersebut. Jadi didapatkan simpulan bahwa terdapat hubungan antara self disclosure dengan trust pada pasangan dewasa muda yang menikah dan menjalani hubungan jarak jauh.

\section{Daftar Pustaka}

Aylor, B. A. (2003). Maintaining LongDistance Relationships. In Canary, D. J., \& Dainton, M (Eds.). Maintaining relationships through comunication: relational, contextual, and cultural variations (pp: 127-134). Online. http://www.lasalle.edu. Diakses 17 November 2014.

Ardianto, A. F. (2015). Angka Perceraian di Banyuwangi Naik. Online. http://m.beritajatim.com. Diakses 25 Juli 2015.

Dainton, M. \& Aylon, Brooks. (2001). A Relational Uncertainty Analysis of Jealousy, Trust, and Maintenance in Long- Distance Versus Geographically Close Relationships. Communication Quarterly, 49 (2), 172-188. Online. http://www.researchgate.net.

Diakses 20 November 2014.

Devito, Joseph. (2011). Komunikasi Antar manusia. (Alih Bahasa : Agus Maulana). Tangerang Selatan: Karisma Publishing Group.

Falk, D.R., \& Wagner, P.N. (2001). Intimacy of self disclosure and response processes as factors affecting the development of interpersonal relationships. The Journal of Social Psychology, 125
(5), 557-570. Online. www.tandfioline.com. Diakses 6 Juni 2015.

Gainau, M. B. (2009). Keterbukaan diri (self disclosure) siswa dalam perspektif budaya dan implikasinya bagi konseling. Jurnal Ilmiah Widya Warta, 33 (1), 95-112. Online. http://puslit2.petra.ac.id. Diakses 17 November 2014.

Gonzalez, C. (2011). Personal and Perceived Partner Commitment and Trust as Predictors of Relationship Satisfaction in Long-Distance and Proximally Close Dating Relationships of Graduate Students. Dissertation. Online. http://digitaldu.coalliance.org. Diakses 20 November 2014.

Guldner. (2014). Long Distance Relationship Frequently Asked Questions. Online. http://www.longdistancerelationshi ps.net. Diakses 15 November 2014.

Gustafson, P. (2006). Work-related travel, gender, and family obligations. Work, employment and society, 20 (3), 513-530. Online. http://wes.sagepub.com. Diakses 5 Maret 2015.

Hamptom, JR.P. (2004). The effect of communication on satisfaction in 
long distance and proximal relationship of college students. LA: Psychology Loyola University N.O.

Johnson, D \& Johnson, F. (2012). Dinamika Kelompok Teori dan Keterampilan. (Alih Bahasa : Theresia, SS). Jakarta: PT INDEKS.

Kauffman, M. H. (2000). Relational Maintenance in Long-Distance Relationships: Staying Close. Thesis. Online. http://scholar.lib.vt.edu. Diakses 16 November 2014.

Laurenceau, J. P., \& Barrett. 2005. The Interpersonal Process Model of Intimacy in Marriage: A DailyDiary and Multilevel Modeling Approach. Journal of Family Psychology, 19 (2), 314-323. Online. http://www.affectivescience.org. Diakses 6 Juni 2015

Lee, Y. J \& Pistole, M. C. (2012). Predictor of Statisfaction Geograpically Close and Long Distance Relationships. Journal of Counseling Psychology, 59 (2), 303-313.

Online. http://www.shu.edu. Diakses 16 November 2014.

Mangundjaya, W. L. H. (2012). Peran Kepercayaan, Keterbukaan dan Sinergi pada proses integrasi Merger dan Akuisisi (Studi pada perusahaan BUMN). Proceedings Temu Ilmiah Ikatan Psikologi Sosial. Pekanbaru, 2-4 November 2012. Online. http://staff.ui.ac.id. Diakses 5 Maret 2015.

Musdalifah. (2012). Menyelamatkan Keluarga Indonesia. Online. http://www.riau.kemenag.go.id. Dikses 15 Januari 2015.

Nugroho, D. A. (2013). Self Disclosure Terhadap Pasangan Melalui Media Facebook di Tinjau dari Jenis Kelamin. Jurnal Online Psikologi, $01 \quad$ (02). Online. http://ejournal.umm.ac.id. Diakses 15 November 2014.

Overwalle, FV \& Heylighen, F (2006), Talking nets: a multiagent connectionist approach to communication and trust between individuals. Psychological Review, 113 (3), 606-627. Online. www.vub.ac.be. Diakses 15 Maret 2015.

Rachma. (2012). "Long Distance Relationship" Jadi Penyebab Tingginya Perceraian. Online. http://www.lensaindonesia.com. Diakses 15 Januari 2015

Rakhmat, J. (2009). Psikologi Komunikasi. Bandung : PT Remaja Rosdakarya.

Seccombe, K., \& Rebecca, L. W. (2004). Marriage and Families: Relationships in social context. Belmont: Thomson Learning Inc.

Simpson, Jeffrey A. (2007). Psychological Foundation of Trust. Association for Psychological Science, 16 (5). Online. https://apps.cla.umn.edu. Diakses 16 November 2014.

Sugiyono. (2013). Metode Penelitian Pendidikan (Pendekatan Kuantitatif, Kualitatif, dan $R \& D)$. Bandung : Alfabeta

Tri. (2015). Memprihatinkan, Banyuwangi Posisi Kedua Nasional Angka Perceraian. Online. http://dprd.jatimprov.go.id. Diakses 25 Juli 2015. 